\title{
Al Ghazali and His Theory of Government
}

\author{
by Khoiruddin Nasution
}

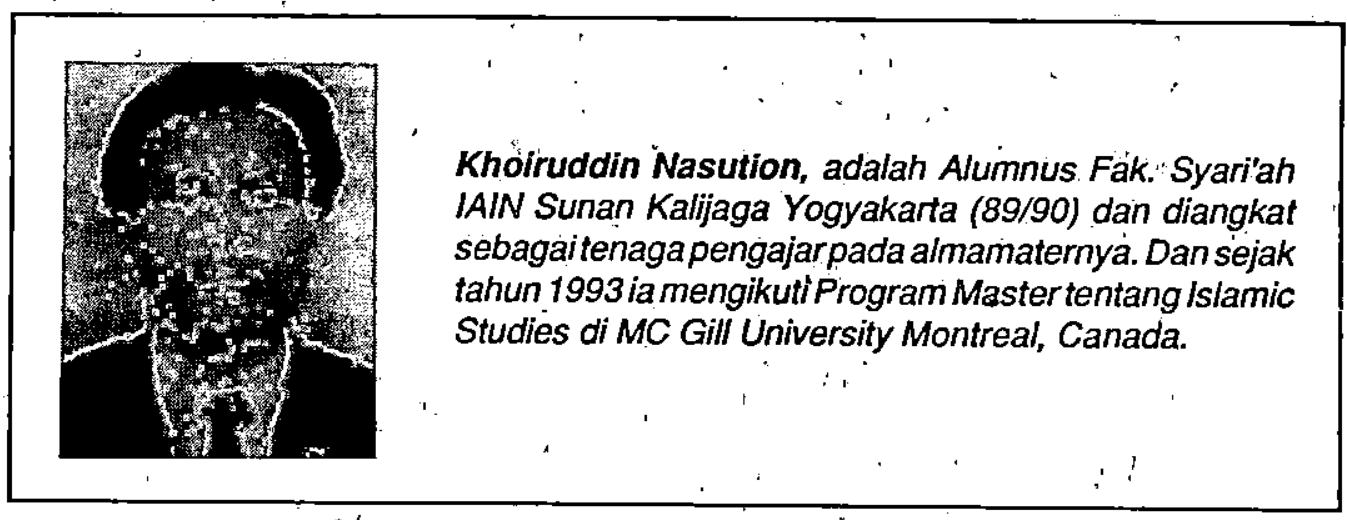

\section{Introduction}

In his article, Islamic Concept of State, Nasim Hasan Shah states that there are many forms of an Islamic state, and every period Muslim comunity discreate most suitable form to their demands, and the most consonant with the spirit of the Shari'a. ${ }^{1}$ That is probably why muslim'thinkers both the earlier and the present period have expressed ideas about Authority in Islam as a dogmatic approach. This is greatly different from alMawardi's administrative approach, Ibn Khaldun's sociological approach and alFarabi's philospohical approaches. 2

This paper will discuss al-Ghazāt's theory of Islamic government. Before discussing this subject, it is necessary to understand al-Ghazär and his works so we are able to understand his theory better. This paper divide into three parts. The first part concerns with al-Ghaz ar's life and his works, the -second part discusses his concept of. Islamic government, and the last.part comprises the conclusion. ,

\section{Al-Ghazāil's Life and Works.}

Abu Hamid Muhammad al-GazāT was born in Tus, ${ }^{3}$ a town near modern Meshhed in northeast Iran, in 1058/450 A.H. Almost since his lifetime, there has been a debate on whether his nisba (relative name), should be considered to be al-Ghazar or Gazzār. The former would relate to village or woman called aIGazâr, while the latter relate to the profession of the spinner or seller of spun yam (ghazzãl). But there is no certainty about the ancestor who was a spinner, since he had a grand-uncle (or less probably an uncle), who was also called al-Ghazār, and the village or woman is othenwise unknown. 4

His early education was in Tūs itself. Here he studied jurisprudence under Abmad ibn Muhammad al-Radhkāñ 5 At some time not later than 1074, al-Ghazār 
went for purposes of study to Gurgan/Jurjan in the south-east of the Caspian Sea. ${ }^{6} \mathrm{He}$ studied further under the Im ām Abū Nasr al-Ismā $C_{1 i}$, and made copious notes: On his way back from Gurjan to Tüs robbers fell upon him, stripped him and even carried off the bag containing his manuscripts, eventually they gave them back to him. ${ }^{7}$ After coming back from Jurjan, al-Ghazẫ stayed at $T \overline{u s}$ for three years, during which he memorized his notes as a precaution against future robbers. ${ }^{3}$.

In 1077 , he went to Nishapur to study under I mām al-Ḥaramayn alJuwayni at the recently founded Nizamiyya college. He remained there until the death of al-Juwayni in August 1085/25th R. Akhir 478 A.H $\mathrm{H}^{8}$. Jurisprudence was presumably the main area of his study. He was also encouraged by al-Juwanyi to read the works of the philosophers alFarabi and Ibn Sina.9 According to Macdonald, the range of his studies embraced, besides Jurisprudence, theology, dialectics, philosophy and logic. 10

He was associated with the court of Nizām al-Mulūk and taught in Nishapur after the death of al-Juwanyi until July 1091/484 A.H., when he was appointed as professor at the Nizâmiyya college in Baghdad: Thus, at the age of 33, he went to one of the most prestigious positions in the Sunnite Islamic world. 11 :

While he was a professor in the Nizāmiyya of Baghdad, he studied philosophy and did some writing. $12 \mathrm{He}$ left Baghdad in November 1095, ostensibly to perform the pilgrimage to Mecca; in fact, this was an excuse to prevent obstacles being placed in the way of his carrying out his real intention of becoming a sufi. He'only went as far as Damascus, and lived there for several months. ${ }^{13}$ According to Macdonald, he appointed his brother Ahmad to teach in his place at the Nizämiyya college: 14

From Damascus, he went to Mecca in November/December 1096 to perform the pilgrimage. He went there passing through Jerussalem and Hebron, ${ }^{15}$ where he visited the grave of Ibrăhm "alKhali1. ${ }^{16}$ He returned back to Baghdad not later then June 1097. But he did not remain there for a long time. He then'went to his home town Tūs, establishing à hostel or Islamic boarding house (khangah), where young men came to join him in leading a sufi life as a community. ${ }^{17}$ According to ${ }^{\mathrm{Abd}}$. alGhafar, when al-Ghazâr finished his pilgrimage, he went to Syria and remained there wandering from place to,place and shrine to shrine for nearly ten years. At this time he composed several works : the Ihya, and books abbreviated from it such as the Arbacin and Rasail, beside laboring at his own spiritual advacement and growth through the religious exercises of the șufis. Then he returned to his home town of Tūs. 18

In 1105 or early in 1106 , he was appointed again as a professor at the Nizāmiyya college in Nishapur by Fakhral-Mulk, son of Nizām al-Mulk. Here, he could combine teaching with the sufi practices which he had been engaged in Tūs. . He continued his teaching at Nishapur until at least August 1:109. He passed away on Monday, 14 Jumadi alAkhir 505 A.H./18 December 1111 in Tùs. 19 
His brother Ahmad tells us about the day of his death :

After making his ablutions and performing the dawn prayer, he asked for his shroud, kissed it, laid it on his eyes and said. "Obediently I enter into the presence of the king, then facing Mecca he stretched out his feet and was dead before sunrise. 20

Hourani has classified al-Ghaz âr's life into four periods. The first is an early period of teaching and writing until the death of Imàm Haramayn al-Juwayní. Only one work is definitely assignable to this time : al-Mankhūl min $\mathrm{Tac}^{\mathrm{C}}$ iqāt al-Usuil. But he also worked on some parts of al-Mustāsfã and al-Munqiìd min alDelal. The second period is a period of retirement, extending for eleven lunar years, from his departure from Baghdad in Dhu al-Qa $\mathrm{c}_{\text {dah }}$ 488/November 1095 to his retum to teach at Nishapur in Dhul al$\mathrm{Qa} \mathrm{c}_{\mathrm{dah}}, 499 / \mathrm{July} 1106$. It was probably during this period that he wrote all or most of his greater work, Ihyā'Ulūm al-Din. The third period began when he came out from retirement in Dhul al-Qha $\mathrm{C}_{\mathrm{dah}} 499$, to resume teaching in Nishapur. The end of this period is not known. He completed his work ạl-Muştasfã during this time. The last period was spent at Tüs, where he lived until his death; the only work which was finished by him during this period is the iljam. 21

The following is a chronological ordering of his works.

1. al-Mankhül min Taclíqāt al-Usūl -- this book is mentioned in al-Mustașfā, and was written during the lifetime of his teacher, Imām al-Haramayn; 2. Shif a $\bar{c}$ al-Ghalil --- unfortunately this book is lost; 3. The following three books related to each other : al-Basit, al-Wasit and al-Wajizz fí Fiqh al-Imām al-Shāfíc $c_{\bar{i}}$; 4. K h u lāsāt al-Mukhtaşar wa Naqāwat al-Muctasar --- this book is mentioned in Ihyyā; 5. Ta hdhỉb al-Uşul -- al-Ghazâr refers to this book in alMustasfa as his own and as a work on Fiqh:22 6. Maqāsid al-Falāsifa --- this book was written in Baghdad; it could not have been started earlier than 1091/1092. Tahăfut al-Falāsifa was completed on Muharram 11,488/ January 21 1095; 7. Micyār al-cllm fi Fann al-Manțiq :this book was anticipated as an appendix to the Ihyā; 8. Mihak al-Nazar fi al-Mantiq -.- this book mentions $\mathbf{M i c}^{\mathbf{c}} \mathbf{y} \overline{a r} ;^{9}$. alMustazhiri -.. this was probably completed after Tahāfut; 10 . Hujjat alHaqq --- this is lost, but is mentioned in Jawāhir al-Qurcān, he wrote it perhaps during his second residence in Baghdad; 11. al-Iqtişād fr al-I $c_{t i q} \bar{a} d$--- it mentions Tahafut, and therfeore cannot be earlier than 1095. it is mentioned in Inyā, therefore earlier than the earliest part of Ihyā. Iqtişàd itself is not easy nor short, it is possible then that it was completed during the second half 1095 ; 12. M izann al-c A mal -.- this was anticipated at the end of Mi'yar; 13. AlRisālah al-Qudsiyya ... this is mentioned in the Ihyā; 14. al-Radd alJamil cala Ilāhiyyāt cIsa bi-Sarih al-Injil --- but Lazarus Yafeh has proved that this book is inauthentic; 15. Ihyā cUlūm ad-Din --- this mentions arRisālah al-Qudsiyya, and al-Iqtişād . He probably did not begin with this book before 490 A.H./1097. This book is 
mentioned in his later works. Unfortunately its date of completion cannot be determined accurately; 16 . alRisālah al-Wac ziyya --- this refers to Qáwācid al-c $\mathbf{c}_{\mathbf{A q}} \mathbf{a}_{\mathbf{i d}} \mathbf{c}_{\text {i.e. Ihya }} \mathbf{c} ; 17$. Ayyuha al-Walad --- mentions Ihyac, 18.al-Imlā fi Ishkālat al-Ihya ${ }^{c}$--- this is printed at the end of $\mathrm{Ihya}_{;} \mathrm{c}_{;}, 19$. alMaqșad al-Asnā fi Sharh $\mathrm{Ma} \mathrm{c}^{\mathrm{a}} \mathrm{i} i$ Asmā Allah al-Husnā --- mentioned in

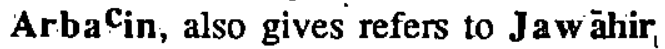
al-Qur'ān; 20. Qaw āşim al-Bāţiniyya -.- mentioned in Jawāhir al-Qur'ān; 21. Jawāb Mufaşşl al-Khilāf --- lost; 22. Jawāhir al-Qur'ān mentions 40 books

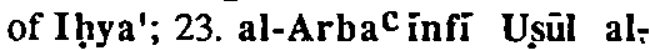
Din --- mentions Bidāya, Maqsad, and describes it self as sequel to Jaw ähir alQur'ān ; 24 Mishka āt al-Anwar -... mentions Ihȳà', Micyaār, Mihakk, al-Maqsad al-Ansā; 25 Kitāb ad-Darj al-Marqūm bi al Jadāwil --- lost; 26 al-Qistās ·al-Mustaqìm --- mentions Jawāhir al-Qur'ān, its sequel Arbai'n Munqidh, polemic work against Isma ${ }^{c_{i l i s m ;}} 27$ Faysal at-tafriqa bayna al-Islam wa al-Zandaga, -- in , al-Jawāhir al-Ghawāif, mentioned in Munqidh; 28. K imíya al-Sa $\mathbf{c}_{\bar{a}}$ dah -.this is likely have to have been composed after al-Ghazār's. retum from the Arab countries; 29. Naşihat al-Mulük --- this work follows closely the organization and the contend of $\mathbf{K}$ imiya al-Sha $\mathbf{a}$ adah; 30. al-Munqidh $\min$ al-Dalāl --mentions the month of his retum to Nishāpur, 31. al-Mustaşfa min' $c_{I}$ lm al-Ușūl al-Fiqh; 32 . Ilj ām al-c $\mathbf{A}$ wām --- completed on the 1st of Jumadi alAkhir, a few days before al-Ghazar death. 23

All the above works are those which are mentioned by majority of scholars interested in studying alGhazāi, 24 but there are many more works which are not usually cited, such as Marāqi al-Zulfa, al-Madnūn bihi cAla Ghayr ahlihi, al-Hikmah fi Makhlūq Allah and so forth. According to Muhammad ibn Hasan's at-Tábaqāt al-cAliyat fì Manāqib al-Shāfící, there are a total of 98 titles of his works. 25

\section{The Concept of Government}

In examining al-Ghazāi unutterable on politics means we must take into consideration the time and circumstance no less than the purpose he had in mind when making them. In Al-Iqtișàd he speaks as a jurist, and the contend is not different from al-Mawardi. Kitāb alMustazhiri ${ }^{26}$ purpose is to establish the legitimacy of the Abbaside caliph alMustazhiri against the opposition of the Batini ya sect who recognized his Fatimah rival. Since effective power was exercised by the Saljuq sultạn, Al-Ghază had to base his claim for the Abbasid caliph's legitimacy on Figh. 27

Naşihiat al-Muluk written by alGhazāi for the great Seljuq Sultān Muhammad ibn Malikshāh, who ruled from 498 to $511 / 1105$ to 1118.28 This book combines with the literary theory, which is something of the theory of the jurists and the philosophers together with traces of the ethic of the Sufis. 29 In Nașịhat al-Mulūk, al-Ghazār writes the only justice and equity of the sul tann true qualification: 30

With regard to the necessity of mām is quite similar in both his book al- 
Iqtișād and kitāb al-Mustazhiri. In Kitāb alMustazhiri, the necessity of Iman is for the advaritage and keeps away damage in the world. The good order should be based on the religious teaching, in contrast, it is not sufficient if merely on the community. The religious order can be achieved just through an Imām who has indeed to be obeyed. ${ }^{31}$ The word Iman is replaced by sultạn. Since the meaning of sultān is authority, power and not the man in power, the ruler. This explanation is taken from the Sunna of the Prophet which states that : "Religion and (temporal) power are twins and a continuation " $"$ therefore it can be concluded that din is the foundation and sultān is the guardian. 32

The first statement by al-Ghaz ar in his book al-Iqtisā fi al-ICtiq âd is that the imāmate or caliphate is an institution prescribed by the Shari'a (rather than a logically necessary institution as the 'Bătinites and philosophers held). ${ }^{33}$.alGhazār attempts to prove that the Imāmāte is necessary for the realization of the Prophet's goal. $\mathrm{He}$ argues that the Prophet's purpose was the formal establishment of the religion of Islam. To secure this end both life and livelihood must be protected. The appointment of an Imàm is, therefore, necessary. His conclusion is that the caliphate (execution of the Shari $\mathrm{c}_{\mathrm{a}}$ ) because of its relationship with the Sultanate (coercive power) is required as a result of the objective of the Prophet (the establishment $r$ and institutionalization of the Shari $\mathrm{c}_{\mathrm{a}}$ ). ${ }^{34}$

al-Ghazail follows the Sunni idea that the Sharic $a$ is the basis of the caliphate. But he adds new elements. First, he states that the caliphate does indeed have utility, but he rests the proof of the Shari $c_{a}$ obligation of appointing an Imām upon two main bases. First, the caliphate is based on $\mathrm{ijm} \overline{\mathrm{a}}^{\mathrm{c}}$. What had been done by the Companions is used by alGhazāT as an example to prove this $\mathrm{ijm} \overline{\mathrm{a}}^{\mathrm{c}}$ basis. He cites the appointment of the Khulafã al Rāshidūn; Abū Bakr al-Siddŕq, cUmar ibn al-Khattāb, Uthmān ibn $\mathbf{c}_{\text {Aff }}$ ân

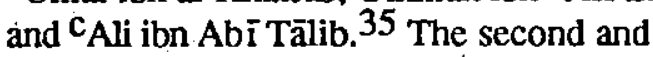
more important basis is deduced will of the Prophet. As noted above, that the purpose of the Prophethood is human beings' happiness. Thus public interest (mașlaha al-umma), such as justice, is the source and reason of the obligation of authority. 36 The requirements of the Shari $\mathrm{c}_{\mathbf{a}}$ imply the requirement of an institution of some, sort to secute them. The form of such an institution has been authorized by the consensus of the community, that is the caliphate. 37 .

al-Ghazari says that there are three ways in which one of those who is qualified for the caliphate may be chosen : by designation of the Prophet, by designation of the ruling caliph as had been done by the Khulafa al-Räshidūn, or by designation of the holder of actual power. He tells us that only the last altemative is applicable in his own day. 38 Designation alone is not sufficient for appointment, for there must be the bay $\mathrm{c}_{\mathrm{a}}$ as well. The bayc $\mathrm{c}_{\mathrm{a}}$ must be performed by the great men and the people of loosing and binding (ahl al-halli wa al-caqd). The great men seem to be the men in power, and those loosing and binding are apparently the ${ }^{C}$ Ulam $\bar{a}$. There is probably a fourth stage in which the appointment is to be realized, that is by announcement in the mosques, and the people are to accept the 
decision handed down from above. ${ }^{39}$

The qualifications of the caliphate in al-Ghazār view are the same as laid down by al-Mawardi. However, in' his book alIqtișād, al-Ghazār just gives four criterias : (1) he must be able to make judgments in accordance with the Shari $\mathrm{C}_{\mathrm{a}}\left(\mathrm{C}_{\mathrm{jilm}}\right)$; (2) he must be able to administer the affairs of state (kifayah); (3) piety (wara); and (4) he must from Qurayshite descent. 40 In Naşinat al-Mulūk, he also mentions the necessity of justice (al-c $\mathrm{Ad}$ alah), the ability to act against enemies (alShujācah), to maintain internal order (mașlaḥah), and sound sight and hearing. ${ }^{41}$ But in doing so he can be helped by his Wazir and the CUlam à 'alGhazār adds that the çaliph must be an $\mathbf{c}_{\text {Abbasid. These requirements are very }}$ great, and it is not surprising that they were in reality never completely fulfilled. The requirement of a Quraishite lineage was the only one to be fulfilled. 42

When his opponents contend that there is no qualified person to serve in that capacity,'al-Ghazar replies by asking : what would become of all these religious, sicial, economic and political phenomena which are regulated by the Sharic $\mathrm{c}_{\mathrm{a}}$ if there were no Caliph. He contends that without the existence of the caliphate no judgment of a qädi, and no testament would be valid, since the power of the $q$ a di and government officials is derived from the caliph. Thus the absence of the caliphate would turn every normal human relationship into sin; and lead to disorder and strife. But he does not say what effect such sosial disintegration might have on the chances of the individual Muslim for salvation. From other indications, we might conclude that they would be conside̊rably reduced. 43

Further, al-Ghazār tells us frankly that the necessity of having an Im àm is so great that it compels the alteration of the qualifications when there is no other way. out. al-Ghazār is willing to concede many of the qualifications in order to maintain the caliphate. As a result, the personal qualification of the caliph are hardly applicable to the nature of the caliphate. 44

al-Ghazari even contends that the sultān is God's shadow on earth. It must, therefore, be recognized that kingship and the divine effulgence have been granted to him by God, and he must accordingly be obeyed, loved and followed. 45 To support this idea, al-GhazâT cites Q.IV : 62 "Obey God and obey the Prophet and those among you who hold authority." 46

al-Ghazār, then, gives much advises which should be followed by the caliphate in conducting the government. For example in the Nașinat al-Muluk he states :

1. The ruler should first of all understand the importance and also the dangers of the authority entrusted to him. 47

2. The ruler should always be thirsting to meet devout ${ }^{C}$ Ulam $\bar{a}$ and to ask them for advice.

3. The king should understand the he must not be content with personally refraining from injustice, but must discipline his slave-troops, servants and officers and never tolerate unjust conduct by them; for he will be interrogated not only about his own unjust deeds but also about those of his staff. 48

4. The holder of authority should not be dominated by pride; for pride gives 
rise to the dominance of anger, and will impel him to revenge. 49

5. The ruler should figure that he is the subject and that the other person is the holder of authority; and that he should not sanction for others anything that he would not sanctiion for himself. 50

6. The ruler should not disregard the attendance of petitioners at his court and should beware of the dangers of doing so.

7. The ruler should not form a habit of indulging passions. 51

8. The ruler should make the utmost effort to behave gently and avoid governing harshly.

9. The ruler should endeavor to keep all the subjects pleased with him. 52

10. The ruler should not give satisfaction to any person if a contravention of God's law would be required to please him; for no harm will came from such persons displeasure. 53 .

He mentions still other things which should be considered by the government in exercising its authority. He cites thesaying that four are incumbent on kings : (1) to purge the realm of ignorable men; (2) to keep the realm prosperous through close co-orperation with wise men; (3) to respect (the opinion of) pious men and pay heed to experienced persons and elders; (4) to increase (the prestige of) the realm by decreasing the number of bad men. 54

al-Ghazar also emphasizes the importance of consultation (sūra) in govemment. But he mentions this advice only to perform a good government. He does not relate it to any possibility that the sultān or caliph be democratically chosen. He cites Q.3 : 153 (:"And consult them in the matter." Q. $20: 30$ - 33.), while discussing the need for the prime minister (wazir) in running the govemment. ${ }^{55}$ al-Ghazār advises further that the king ought to observe three principles in his treatment of the wazir $\mathrm{r}: 56$ (1) not to punish him in haste when vexed with him; (2) not to covet his wealth when he grows rich; and (3) not to refuse him a (necessary) request when he makes one. Similarly, the king ought to grant three facilities to the wazir : (1) to let him see the king whenever he wishes; (2) not to listen to talk by slanderers against him; and (3) not to keep secret from him. 57

The nature of al-Ghazar's theory now becomes much clearer : a) The caliphate comprehends the necessary power to accomplish the maintenance of order of the community, b) It represents of symbolizes the collective unity of the Muslim community and its historical continuity, c) Deriving its functional and institutional authority from the Sharica, it is the only legitimate form of government in Islam. Therefore, there are three aspects of the caliphate which correspond to alGhazârs theory : (1) utility; (2) ijmâ'; (3) the objective of the Prophet.

\section{Conclusion}

al-Ghazār felt justified in validating the government of the Sultạn. He was willing to make concessions regarding a limited number of the Shari'a regulations in order to preserve the religious life of the community. In contrast, he indeed did not consider much the possibility of every Muslim to.be a khalif, since al-Qur'an also emphasizes this possibility. There are several verses, which indicate this phenomenon: For example, Q. $49: 13$, in 
which stated that the noblest is the best in conduct. There are still many different verses which indicate similar meaning.

The Caliphate is the religious institution as well as the political institution of Islam. al-Ghazär has a multilateral conception of the caliphate. There are three main elements of his conception : the caliph, the sultạn and the 'ulamā; each corresponding to some aspects of the authority behind Islamic government, and each performing a function required by that authority. alGhazar argues for the independence of the 'Ulamā, and' he urges them to resist the blandishments of the Sultạn. In fact, alGhazāi seeks to explain the political conditions of his. own time in terms acceptable to traditional Sunni thought. He does not discuss this theory how it should be, based merely on Qur'anic value.

al-Ghazār envisages a multilateral rather than a unitary govemment. He also associates the caliph with sulțän. This is really different from al-Mawardi's theory, which lays down one man-govemment. al-Ghazār does not specify any caliph functions or suggest that the caliph is under a contractual obligation toward the Muslim community to fulfill such functions. al-Ghazār's argument shows clearly that he did not expect that any of the military; administrative or religious functions of government would actually be exercised by the caliph; they would be exercised by Turks, the wazir, the secretaries, and by the 'ulamā.

\section{Bibliographies.}

Badawi, 'Abd. al-Raḥman, Muallafāt al-Ghazālí. Kuwait : Kit ābat al-
Mạbu'at, 1977.

Binder, Leonard, "al-Ghazāir's Theory of Islamic Government," The Muslim. World, 45 (1955).

al-Ghazāi, al-Iqtiṣād fí al-I'tiqāa . Caimo : al-Tijāriyah, n.d.

- Ihyyā 'Ulūm' al-Dín. Miṣr : alMaktabat al-Tijāriyah al-Kubrā, n.d. al-Münidh min al-Dalāl . Cairo : Maktabat al-Anjal $\bar{u}$, 1952/1372 H.

-- Na șịhat al-Mulūk, trans.

Counsel for Kings, by F.C.

Bagley. London : Oxford University Press, 1964.

Goiten, S.D., "The Origin of the Vizierate and Its True Character," Islamic Culture, 16 (1942).

Hourani, George F., "The Chronology of al-Ghazār's Writing"; Jornal of the American Oriental Society, 79 (1959).

A Revised Chronology of alGhazār's Writing, Journal of the American Oriental Society, 104, 1 (1984) .

Lambton, Ann K.S., "The Theory of Kingship in the Nașịạat al-Mulūk of al-Ghazār," Islamic Quarterly, 1 (1954).

Lazarus-Yafeh, Hava, Studies in alGhazzali. Jerussalem : The Magnes Press, The Hebrew University, 1975.

Macdonald, Duncan B., "The Life of alGhazär., with especial reference to his religious experiences and opinions, "Journal of the American Oriental Society, 20 (1899). al-Mawardi, al-A hkäm al-Sul țantiyah. Miṣr : al-Sa'ādah, 1909/1328 H. Mozaffari, Mehdi, Authority in Islam. 
London : M.E. Sharpe, Inc., 1987. Rosebthal, Erwin I.J., Political Thought in Medieval Islam : An introduction Outline. Cambridge.: The University Press, 1962.

Shah, Nasim Hasan, "Islamic Concept of 'State", Hamdard Islamicus, 10, 3 (1987).

Siddiqi, Amir Hasan, Caliphate and Sultanate. Karachi : Jamiyat-ul Falah Publication, 1969.

Lewis, B.V.L. Menage, CA. Pellat and J. Schacht. Encyclopedia of Islam, "al-Ghazar" by W. Montgomery Watt.

Watt, W. Montgomery, Islamic Philosophy and Theology.: An Extended Survey Edinburgh : The University Press, 1985.

\section{CATATAN KAKI :}

1. Nasim Hasan Shah. "Islamic Concept of State," Hamdard Islamicus, 10, 3 (Autum, 1987), 39.

2. Mehdi Mozaffari, 'Authority in Islam (London : M.E. Sharpe, Inc., 1987), 8-14.

3. Duncan G. Macdonald, "the Life of alGhazali, with special reference to his religious experiences and opinions," Journal of the American Oriental Society, 20 (1899), 74. See also Encyclopedia of Islam, new edn. "alGhazāil," by W. Montgomery Watt, vol. 2, 1038-41.

4. W. Montgomery Watt, Islamic Philosophy and Theology : An Extended Survey (Edinburgh : The University Press, 1985), 86. 76. Op.cit.

5. Macdonald, "The Life of al-Ghazäli,"

6. Watt, Islamic Philosophy, 86. Op.cit.

7. Macdonald, "The Life of al-Ghazāì̄,"
76. Op.cit.

8. Ibid; 77.

9. Watt, Islamic Philosophy, Loc. cit., 86.

77. Op.cit.,

10. Macdonald, "The Life of al-Ghazàli," Loc.cit.,

11. Watt, Islamic Philosophy, 86.

12. Ibid., 86. Loc.cit.

13. Ibid., 88. Op.cit.,

14.'Macdonald, "The Life of al-Ghazāị," 79-80. Op.cit.,

15. Watt, Islamic Philosophy, 88.

16. Macdonald, "The Life of al-Ghazāin," 93. Op.cit., Loc.cit.

17. Watt, Islamic Philosophy, 88. 97. Op.cit.,

18. Macdonald, "The Life of al-Ghazālī,"

19. Ibid., 107. See also Watt, Islamic Philosophy, Op.cit., 89.

20. Watt, Islamic Philosophy, 89. see also Encyclopedia of Islam vol. 2, "al-Ghazāin" by W. Montgomery Watt, Loc.cit., 1039.

21. Macdonald, "The Life of al-Ghazali," 290-291. see also al-Ghazäli, al-Munqidh min al-Dalal (Cairo : Maktabat al-anjilū al-Misriyat, n.d.).

22. This book is more detail than alMustasfa. But Bouyges rejected this idea because he could not believe that al-Ghazali wrote a book on Fiqh longer than al-Mustașā.

23. George F. Hourani, "The Chronology . of Ghazali's Writing," Journal of the American Oriental Society, 79 (1959), 255-233. ----"ARevised Chronology of Ghazäli's Writing", Journal of the American Oriental Society, 104, 1 (Januari-March 1984), 289-302.

24. See W. Montgomery Watt, "The Authenticity of the works attributed to alGhazālī," Royal Asiatic Society (1952), 25-45. 
25. Unfortunately this book is still manuscript and there is not available in the Islamic Studies library of McGill University. Also see 'Abd. al-Rạ̣män Badawi, Muallafät alGhazäli (Kuwait : Kitābat al-Mạbü'àt, 1977). in which the author examines the authenticity of each book : Hava Lazarus Yafeh, Studies in alGhazali (Jerussalem : The Magnes Press, 1975), where the author explains the covabulary and method used by al-Ghazäli.

26. Unfortunately this book is not available in Islamic library of McGill University.

27. Erwin I. J. Rosenthal, Political Thought in Medieval Islam : An lritroductory Outline (Cambridge : The University Press, 1962), 39.

28. Ann K. S. Lambton, The Theory of Kingship in the Nasiihat al-Mulük of Ghazalii, Islamic Quarterly, 1, i (1954), 47.

29. Ibid.

30. Ibid., 54.

31: Ibid.

32. al-Ghazālì, Iqtișād fi al-l'tiqāt (Cairo : At-Tijariya, n.d.), 95. from medieval, 39. See also Amir Hasan Siddiqi,'Caliphate and Sultanate in Medieval Persia (Karachi : Jamiyat-ul Falah Publication, 1969), third ed., 147.

33. al-Ghazäli, Al-Igtișäd, 105.

34. Ibid., 106.

35. Ibid., 109. See also Leonard Binder, "al-Ghazalii's Theory of Islamic Government," The Muslim World, 45 (1955). 230.

36. Ibid., 107.
37. Ibid., 108.

38. al-Ghazài, Ihyä'Ulüm al-Din, vol. 2 (Mișr : al-Maktabat al-Tijāriyah al-Kubrā, n.d.), 124-126.

39. al-Ghazālī, al-Iqtiṣăd, op.cit., 107.

40. al-Ghazāàì, al-Jqtișäd, op.cit., 106.

41. al-Ghazălì, Nașihat al-Mulük, trans. Counsel for Kings, by F.R.C. Bagley (London : Oxford University Press, 1964), 14-31. See also al-Mawardi, al-Aḥkàm al-Sulıäniyah (Mișr : alSa’àdah, 1909/1328 H), 4.

42. al-Ghazālì, al-Iqtiṣäd, 106.

43. al-Ghazàìi, al-Igtișäd, 106. Loc.cit.

44. al-Ghazàlì, Ihyā', 125

45. al-Ghazāli, al-lqtișād, 10̀7. Op.cit.

446. al-Ghazäli, Nașihat, 45.

47. Ibid., 14

48. Ibid., 23

49. Ibid., 25

50. Ibid., 28-29

51. Ibid., 29

52. Ibid., 30

53. Ibid., 31

54. Ibid., 85

55. Mozaffari, Authority In Islam, 13.

56. To understand the word and the usage history of wazir see S.D. Goitein, "The Origin of the Vizierate and its True Character," Islamic Cullure, 16 (1942).

57. al-Ghazāili, Nașihat al-Mulük, 106 107. 